\title{
Chemical and immunological analysis of the Aspergillus fumigatus cell wall
}

\author{
V. M. Hearn't and J. H. Sietsma ${ }^{2}$ \\ Author for correspondence: V. M. Hearn. Tel: +33 76765490. Fax: +3376765660.
}

1 Mycological Reference Laboratory, Central Public Health Laboratory, Colindale, London, UK

2 Department of Plant Biology, University of Groningen, The Netherlands

\begin{abstract}
Hyphal-wall preparations of Aspergillus fumigatus have been analysed by sequential treatment with KOH, nitrous acid and again with KOH. By acidification of the alkali-soluble extract, a polyglucose was precipitated which showed an X-ray diffraction pattern similar to that of $(1 \rightarrow 3)$ - $\alpha$-glucan. The remainder of the alkali-soluble fraction was precipitated with ethanol; it contained all the mannose, galactose and protein of the wall and, in addition, $6.2 \%$ of the amino sugars. This wall-associated glycoprotein, following SDSPAGE and immunoblotting, reacted with antisera raised against several mycelial extracts of $A$. fumigatus. Sera from patients with aspergilloma have antibodies which recognize components of this glycoprotein. The glycoprotein nature of these antigens was shown by their ability to bind Lens culinaris lectin. In addition, the antigen/antibody binding could be disrupted by exposure of antigen to periodate oxidation, hydrolysis with dilute acid or pretreatment with a large excess of an exo- $\beta$-D-galactofuranosidase. The alkaliinsoluble fraction consisted of a covalently linked glucan-chitin complex. Nitrous acid treatment, which specifically disrupts glycosidic linkages involving glucosamine, did not solubilize much material but changed the $X$-ray diffraction pattern from diffuse to a pattern showing the characteristic lines of crystalline $(1 \rightarrow 3)$ - $\beta$-glucan and chitin. Most of the glucan became alkali-soluble after this treatment, and the insoluble residue appeared to contain crystalline chitin.
\end{abstract}

Keywords: Aspergillus fumigatus, cell wall, immunological activity

\section{INTRODUCTION}

The nature of the cell wall of Aspergillus fumigatus has received attention, partly because the potential of its surface structures as diagnostic antigens has long been recognized (Drouhet et al., 1972). Electron microscopy studies have shown that specific immunoglobulin from the serum of patients with antibodies to Aspergillus and from antisera raised in rabbits to $A$. fumigatus fractions bound almost exclusively to the mycelial cell wall (Hearn et al., 1991).

It is known from chemical analysis that the cell wall of Aspergillus contains predominantly glucan, chitin and galactomannan (Azuma et al., 1969). Water extraction of $A$. fumigatus mycelium yielded a glycoprotein with

tPresent address: Laboratoire de Parasitologie, $\mathrm{CHU}$ Albert MichallonBP 17X, 38143 Grenoble Cedex, France.

Abbreviations: ConA, concanavalin $A_{i}$ LCA, Lens culinaris agglutinin; WGA, wheat germ agglutinin. immunological activity (Azuma et al., 1968). We report here on the chemical and immunochemical analysis of components of the mycelial cell wall.

\section{METHODS}

Organism and culture conditions. A. fumigatus strain NCPF 2109 was grown in neutral glucose/peptone broth at $30^{\circ} \mathrm{C}$ for $3 \mathrm{~d}$. The mycelium was harvested by filtration, washed several times with water and stored at $-20^{\circ} \mathrm{C}$ until required.

Preparation of cell walls. The mycelial pad was thawed, suspended in $50 \mathrm{mM} \mathrm{NH}_{4} \mathrm{HCO}_{3}$ at $\mathrm{pH} 8.0$ and disrupted with Ballotini beads, diameter $0.75-1.0 \mathrm{~mm}$, at $5^{\circ} \mathrm{C}$ in a Dynomill cell disintegrator. The cell homogenate was separated from the glass beads by decantation. The wall pellet was collected by centrifugation at $5000 \mathrm{~g}$ at $4{ }^{\circ} \mathrm{C}$, washed several times with $\mathrm{NH}_{4} \mathrm{HCO}_{3}$ buffer, washed finally with water and freeze-dried.

Cell wall fractionation. The wall preparation was extracted twice with $1 \mathrm{M} \mathrm{KOH}$ at $60^{\circ} \mathrm{C}$ for $20 \mathrm{~min}$ under $\mathrm{N}_{2}$. The alkaline extract was acidified with acetic acid to $\mathrm{pH} 5.0$ and the precipitated matesial collected by centrifugation and washed with water. To the supernatant was added 2 vols ethanol. The 
precipitate was collected by centrifugation and washed with $64 \%(\mathrm{v} / \mathrm{v})$ ethanol. This was labelled the glycoprotein fraction. Both fractions were freeze-dried and stored at $-20{ }^{\circ} \mathrm{C}$ until required. The alkali-insoluble material was washed several times with water, freeze-dried and stored at $-20^{\circ} \mathrm{C}$. For the nitrous acid treatment the alkali-insoluble fraction obtained from $50 \mathrm{mg}$ cell wall material was suspended in $1 \mathrm{ml}$ water, $1.5 \mathrm{ml} 2 \mathrm{M}$ $\mathrm{NaNO}_{2}$ and $0.5 \mathrm{ml} 2 \mathrm{M} \mathrm{HCl}$. The tube was closed tightly and shaken vigorously at room temperature for $1.5 \mathrm{~h}$. On opening the tube, air was bubbled through $(15 \mathrm{~min})$ to remove the volatile nitrogen oxides. The insoluble material was collected by centrifugation, washed with water and extracted with $1 \mathrm{M} \mathrm{KOH}$ at $60{ }^{\circ} \mathrm{C}$ for $20 \mathrm{~min}$. The extracted material was precipitated with 2 vols of ethanol, washed with $64 \%(v / v)$ ethanol and dried.

Analytical methods. Total carbohydrate content in hydrolysed and unhydrolysed samples was determined with the anthrone reagent (Fairbairn, 1953). Total hydrolysis was achieved by solubilizing the sample in $90 \%(\mathrm{v} / \mathrm{v})$ formic acid in a boilingwater bath under $\mathrm{N}_{2}$ for $15 \mathrm{~min}$. Alternatively, the material was dissolved in $6 \mathrm{M} \mathrm{HCl}$ at $120^{\circ} \mathrm{C}$ under $\mathrm{N}_{2}$ for $15 \mathrm{~min}$. Formic acid or $\mathrm{HCl}$ was then evaporated in vacuo over $\mathrm{P}_{2} \mathrm{O}_{5}$ and $\mathrm{KOH}$ in a desiccator. The residue was dissolved in $250 \mathrm{mM} \mathrm{HCl}$ and hydrolysis completed in the presence of Dowex $50 \mathrm{~W}-\mathrm{X} 8$ (200-400 mesh) in the $\mathrm{H}^{+}$-form for $16 \mathrm{~h}$ at $100^{\circ} \mathrm{C}$. The Dowex was eluted with 1 vol. water to collect the neutral sugars and then with 5 vols $2 \mathrm{M} \mathrm{HCl}$ to collect amino sugars. Eluates were taken to dryness and dissolved in water. In hydrolysed samples total hexosamine was estimated by the method of Johnson (1971) and reducing sugars estimated using the method of Nelson \& Somogyi (Nelson, 1944), while glucose and galactose were determined with glucose oxidase and galactose oxidase reagents, respectively (Boehringer Mannheim). Mannose was determined by subtracting the values for glucose and galactose from the value for reducing sugars, assuming that these three sugars were the only reducing sugars present. This was confirmed by TLC, which was done on a cellulose plate using, as solvent, pyridine/ethyl acetate/acetic acid/water $(5: 5: 1: 3$, by vol.). Reducing sugars were visualized by spraying the plate with aniline phthalate reagent (Stahl, 1969).

Periodate oxidation was done by treating the alkali-soluble fraction with $15 \mathrm{mM}$ sodium periodate at $4{ }^{\circ} \mathrm{C}$ in the dark for $48 \mathrm{~h}$. The periodate consumption was followed by measuring the decrease in $A_{222}$. The glycoprotein fraction was treated with $50 \mathrm{mM}$ sodium periodate at room temperature in the dark for 2 or $18 \mathrm{~h}$. Protein was determined in the $1 \mathrm{M} \mathrm{KOH}$ extract using the Lowry method.

The sensitivity to acid of the antigenic properties of the glycoprotein fraction was determined by treatment with dilute $\mathrm{HCl}\left(\mathrm{pH} 2.0\right.$ at $100^{\circ} \mathrm{C}$ for $20 \mathrm{~min}$ ) and drying over $\mathrm{KOH}$, prior to electrophoresis and blotting.

$\mathrm{X}$-ray diffraction. X-ray diffraction patterns were obtained from powdered freeze-dried wall fractions. Spectra were recorded on a flat-film camera at a distance of $40 \mathrm{~mm}$ from the specimen. Nifiltered $\mathrm{Cu} \mathrm{K} \alpha$ radiation was used from a Philips fine-focus tube.

Antigenic fractions from $\boldsymbol{A}$. fumigatus mycelium. Surface extracts solubilized in bicarbonate, a total water-soluble preparation, a protein-enriched (non-Con $\mathrm{A}$ binding) fraction and a carbohydrate-enriched (ConA-binding) fraction were obtained as reported elsewhere (Hearn \& Mackenzie, 1979; Wilson \& Hearn, 1983; Hearn, 1991).

Rabbit antisera. Antisera were obtained by hyperimmunization of New Zealand White rabbits. For the glycoprotein fraction amounts of $0.3 \mathrm{mg}$ dry wt were used per injection, while for the predominantly carbohydrate antigen amounts of $10 \mathrm{mg}$ dry wt were used per injection (Hearn et al., 1990).

SDSPAGE. Vertical PAGE with a separating gel of $10 \%(\mathrm{w} / \mathrm{v})$ polyacrylamide containing $0 \cdot 1 \%(\mathrm{w} / \mathrm{v})$ SDS was done according to Laemmli (1970). Samples for analysis were taken up in disrupting buffer $(2 \%, \mathrm{w} / \mathrm{v}, \mathrm{SDS} ; 10 \%, \mathrm{v} / \mathrm{v}$, glycerol $; 5 \%$, $\mathrm{v} / \mathrm{v}, \beta$-mercaptoethanol; plus a trace of bromophenol blue in Tris/ $\mathrm{HCl}$ buffer, $\mathrm{pH} \mathrm{6.8)} \mathrm{and} \mathrm{boiled} \mathrm{for} 10$ min before application to the wells. High molecular mass protein standards (14.3-200 kDa; Gibco) were electrophoresed in parallel (Hearn et al., 1990). Separated components were stained for protein using $0.1 \%(\mathrm{w} / \mathrm{v})$ Coomassie Brilliant Blue R-250.

Electroblotting. The electrophoretically separated molecules were electro-transferred to nitrocellulose membranes (Hybond C, Amersham) in a transblotting chamber (Towbin et al., 1979). Blots were stained for protein with India ink $(0.1 \%$ in PBS/Tween 20) for $1 \mathrm{~h}$ at room temperature (Hancock \& Tsang, 1983).

Lectin treatment. Lectins were chosen as probes on the basis of their specificity for selected sugar residues known to occur in $A$. fumigatus mycelium. Con A and wheat germ agglutinin (WGA) were peroxidase conjugates; Lens culinaris agglutinin (LCA) was biotin labelled. All lectins were purchased from Sigma. Details of the conditions for incubation are reported elsewhere (Hearn et al., 1989).

Reactivity of antigens. Sera at appropriate dilutions were incubated with transblotted antigens; antigen/antibody complexes were detected with anti-human or anti-rabbit IgG, peroxidase conjugated. The substrate for the peroxidase reaction was diaminobenzidine (Hearn et al., 1990).

Enzyme treatment of glycoprotein. A. fumigatus glycoprotein was incubated separately with two different hydrolases and with galactose oxidase following SDS-PAGE and transblotting. $\alpha$-Mannosidase from jack bean (EC 3.2.1 .24; from both Sigma and Boehringer Mannheim) was used at $50 \mathrm{U} \mathrm{ml}^{-1}$ in $100 \mathrm{mM}$ sodium acetate, $\mathrm{pH} 5.0$, for $18 \mathrm{~h}$ at $37^{\circ} \mathrm{C}$ (Zamze et al., 1991). Reactions using an exo- $\beta$-D-galactofuranosidase, prepared from Trichoderma barzianum, were kindly performed by A. W. van Bruggen-van der Lugt of the Agricultural University, Wageningen, the Netherlands. Briefly, blots were incubated in $200 \mathrm{mM}$ sodium acetate, $\mathrm{pH} 5 \cdot 0$, for $16 \mathrm{~h}$ at $30^{\circ} \mathrm{C}$. The enzyme fraction contained $100 \mu \mathrm{g}$ of protein, equivalent to $30 \mathrm{mU}$ of enzyme. Blotted glycoprotein components were exposed to galactose oxidase (EC 1.1.3.9; Sigma) at $50 \mathrm{U} \mathrm{ml}^{-1}$ in $100 \mathrm{mM}$ potassium phosphate, $\mathrm{pH} 6.0$, for $2 \mathrm{~h}$ at room temperature (Alon et al., 1991). Subsequent to enzyme treatments, blots were washed with PBS/Tween 20 and probed with homologous antiserum diluted $1: 50$.

\section{RESULTS}

\section{Composition of the hyphal wall}

The chemical composition of the hyphal wall of $A$. fumigatus is shown in Table 1 . By using the anthrone reaction and glucose as the standard it appeared that $71.5 \%$ of the dry weight of the wall consisted of anthronereacting carbohydrate material. The monomeric composition was determined by TLC after complete hydrolysis of the wall; glucose, glucosamine, galactose and mannose were detected. The amounts of glucose and galactose were estimated by specific enzymic assays, and the mannose content was determined as the difference between the total carbohydrate value (anthrone) adjusted for the molar absorption ratios of galactose and mannose 
Table 1. Composition of the hyphal wall of $A$. fumigatus

Figures in parentheses represent the percentage of the complete fraction. Total carbohydrates were determined in unhydrolysed samples as anthrone-positive material; amino sugars were determined in hydrolysed samples; glucose was determined in hydrolysed samples with the glucose oxidase test; galactose was determined in hydrolysed samples with the galactose oxidase test; mannose was determined by subtracting the glucose and galactose values from the anthrone value; protein was determined in the alkali-extract with the Lowry test.

\begin{tabular}{|c|c|c|c|c|c|c|}
\hline \multirow[t]{3}{*}{ Component } & \multicolumn{6}{|c|}{ Percentage of dry weight of hyphal wall } \\
\hline & \multirow{2}{*}{$\begin{array}{l}\text { Complete } \\
\text { wall }\end{array}$} & \multicolumn{2}{|c|}{ Alkali-soluble (1 M KOH) } & \multicolumn{3}{|c|}{ Alkali-insoluble } \\
\hline & & $\begin{array}{c}\text { Acid } \\
\text { precipitable }\end{array}$ & $\begin{array}{c}\text { Ethanol } \\
\text { precipitable }\end{array}$ & $\begin{array}{c}\mathrm{NO}_{2}^{-} \\
\text {soluble* }\end{array}$ & $\begin{array}{c}\text { Alkali } \\
\text { soluble } f\end{array}$ & Insoluble $\dagger$ \\
\hline Total carbohydrates & $71 \cdot 5$ & $17 \cdot 2$ & $18 \cdot 5$ & $5 \cdot 4$ & $29 \cdot 2$ & $1 \cdot 2$ \\
\hline Reducing sugars & $81 \cdot 0$ & $17 \cdot 6$ & $13 \cdot 2$ & 3.6 & $30 \cdot 4$ & $16 \cdot 2$ \\
\hline Amino sugars & $18 \cdot 4$ & $0 \cdot 2(1 \cdot 0)$ & $1 \cdot 2(5 \cdot 8)$ & $0 \cdot 9$ & $2 \cdot 8(8.9)$ & $13 \cdot 3(89 \cdot 9)$ \\
\hline Glucose & $58 \cdot 4$ & $17 \cdot 5(88 \cdot 8)$ & $5 \cdot 4(26 \cdot 2)$ & $5 \cdot 5$ & $28 \cdot 5(91 \cdot 1)$ & $1 \cdot 5(11 \cdot 1)$ \\
\hline Galactose & $4 \cdot 1$ & & $4 \cdot 2(20 \cdot 4)$ & & & \\
\hline Mannose & $3 \cdot 6$ & & $3 \cdot 6(17 \cdot 5)$ & & & \\
\hline Protein & $8 \cdot 2$ & $2 \cdot 0(10 \cdot 3)$ & $6 \cdot 2(30 \cdot 1)$ & & & \\
\hline
\end{tabular}

* Due to the interference of $\mathrm{NO}_{2}^{-}$ions in several analytical tests, these values are calculated by subtracting the alkali-soluble and insoluble values from the values found in the complete fraction. The $\mathrm{NO}_{2}^{-}$treatment was done by susperding the material in $1 \mathrm{M} \mathrm{NaNO}_{2}$ at $\mathrm{pH} 3$ for $1.5 \mathrm{~h}$ at room temperature.

† Second $\mathrm{KOH}$ extraction.

and the glucose and galactose values (glucosamine does not react with anthrone).

Completely hydrolysed walls consisted of $81.0 \%$ of reducing sugars, based on glucose as the standard. If the amounts of glucosamine, glucose and galactose were subtracted from this value, after adjusting for the molar absorption ratios of these substances, the amount of mannose was $3.5 \%$, which is close to the value based on the anthrone assay.

Glucosamine was the only amino sugar detected in completely hydrolysed walls by a colorimetric assay as well as by TLC. Because the acetyl group is removed during hydrolysis, the amino sugar could be present in the native wall as both glucosamine and/or $N$-acetylglucosamine. Glucosamine-containing polymers are sensitive to nitrous acid treatment, which hydrolyses the glycosidic linkages between the glucosamine monomers converting them into 2,5-anhydromannose. Polymers of $N$ acetylglucosamine resist this treatment (Shively \& Conrad, 1970; Datema et al., 1977). Treatment of the alkali-resistant fraction with nitrous acid $(\mathrm{pH} 3)$ removed $4.9 \%$ of the total amount of amino sugars, indicating that this could be present as glucosamine in the mature cell wall, with the remaining $95 \cdot 1 \%$ as $N$-acetylglucosamine.

\section{Composition of the alkali-soluble fraction}

Extraction of the wall with $1 \mathrm{M} \mathrm{KOH}$ removed approximately half of the anthrone-positive material. The precipitate formed on acidification of this fraction with acetic acid to $\mathrm{pH} 5.0$ consisted of $88.8 \%$ glucose (Table 1 ). It showed an $\mathrm{X}$-ray diffraction pattern which resembled that of alkali-soluble $(1 \rightarrow 3)$ - $\alpha$-glucan (Fig. 1B). It could not be oxidized by periodate, indicating that only $(1 \rightarrow 3)$ linkages were present.

The remainder of the alkali-soluble material was precipitated with ethanol, and probably consisted of glucomanno-galacto-protein because it contained all the mannose, galactose and protein present in the wall. It contained $5.8 \%$ amino sugars, probably in the form of $N$ acetylglucosamine. It was not present in a crystalline form for it did not show an X-ray diffraction pattern.

\section{Composition of the alkali-insoluble fraction}

After complete hydrolysis this fraction consisted entirely of glucose and glucosamine (Table 1).

Nitrous acid treatment $(\mathrm{pH} 3)$ removed from the unhydrolysed fraction $5.3 \%$ of the amino sugars (which apparently were present as glucosamine) and $15.5 \%$ of the glucose.

Subsequent treatment of this fraction with $1 \mathrm{M} \mathrm{KOH}$ at $60{ }^{\circ} \mathrm{C}$ dissolved the rest of the glucan almost completely. Hydrolysis showed it to consist of $91.1 \%$ glucose (Table 1) while $X$-ray diffraction analysis showed a pattern similar to hydroglucan [crystalline $(1 \rightarrow 3)$ - $\beta$-glucan] (Jelsma \& Kreger, 1979). Fig. 1(C) shows the diffraction pattern before nitrous acid treatment and Fig. 1(D) the diffraction pattern after the nitrous acid treatment. The hydroglucan diffraction lines became more pronounced after this treatment and disappeared on subsequent alkali extraction (Fig. 1E).

The fraction which remained alkali-insoluble after nitrous acid treatment consisted of $89.9 \%$ amino sugars (Table 1 ), 


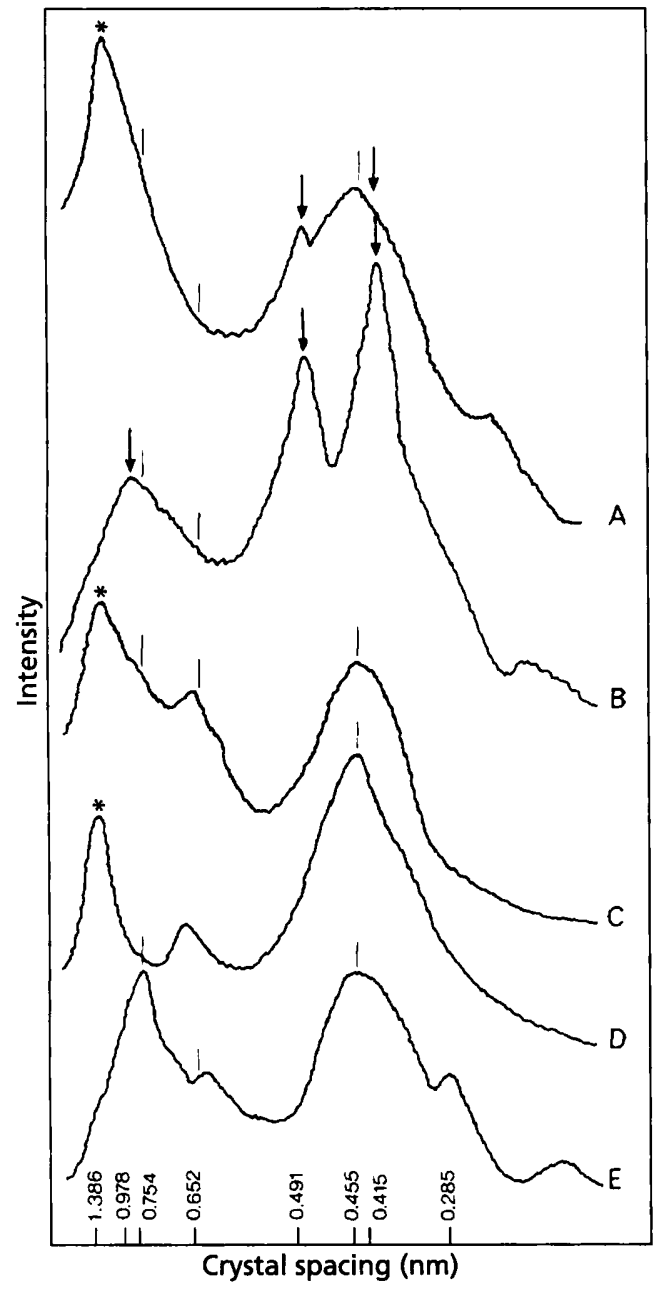

Fig. 1. Radial density tracings of $X$-ray powder diagrams of hyphal wall fractions of $A$. fumigatus. $A$, untreated wall; $B$, fraction soluble in alkali and precipitable with acetic acid; $C$, alkali-insoluble fraction; D, the same as $C$ but treated with nitrous acid; $E$, the same as $D$ but extracted with $1 \mathrm{M} \mathrm{KOH}$. Asterisks indicate characteristic hydroglucan $[(1 \rightarrow 3)-\beta$-glucan] spacings; vertical bars indicate characteristic chitin spacings; arrows indicate spacings characteristic for $(1 \rightarrow 3)$ - $\alpha$-glucan.

probably $N$-acetylglucosamine because of its resistance to nitrous acid. In addition, it displayed an X-ray diffraction pattern which is characteristic of crystalline chitin (Fig. $1 \mathrm{E})$.

\section{Immunological analysis of the alkali-soluble fraction}

The material extracted with $1 \mathrm{M} \mathrm{KOH}$, following acidification and precipitation with ethanol, was solubilized in disrupting buffer for electrophoresis by SDS-PAGE. Separated components were stained for protein with Coomassie Blue, which revealed a major band doublet of apparent molecular mass $60-61 \mathrm{kDa}$ (not shown). Following electrophoretic separation and subsequent transfer to a nitrocellulose membrane, this material was stained for protein with India ink. Bands with apparent molecular masses of $38,60,66$ and $68 \mathrm{kDa}$ were visualized by this procedure (Fig. 2, lane 1).

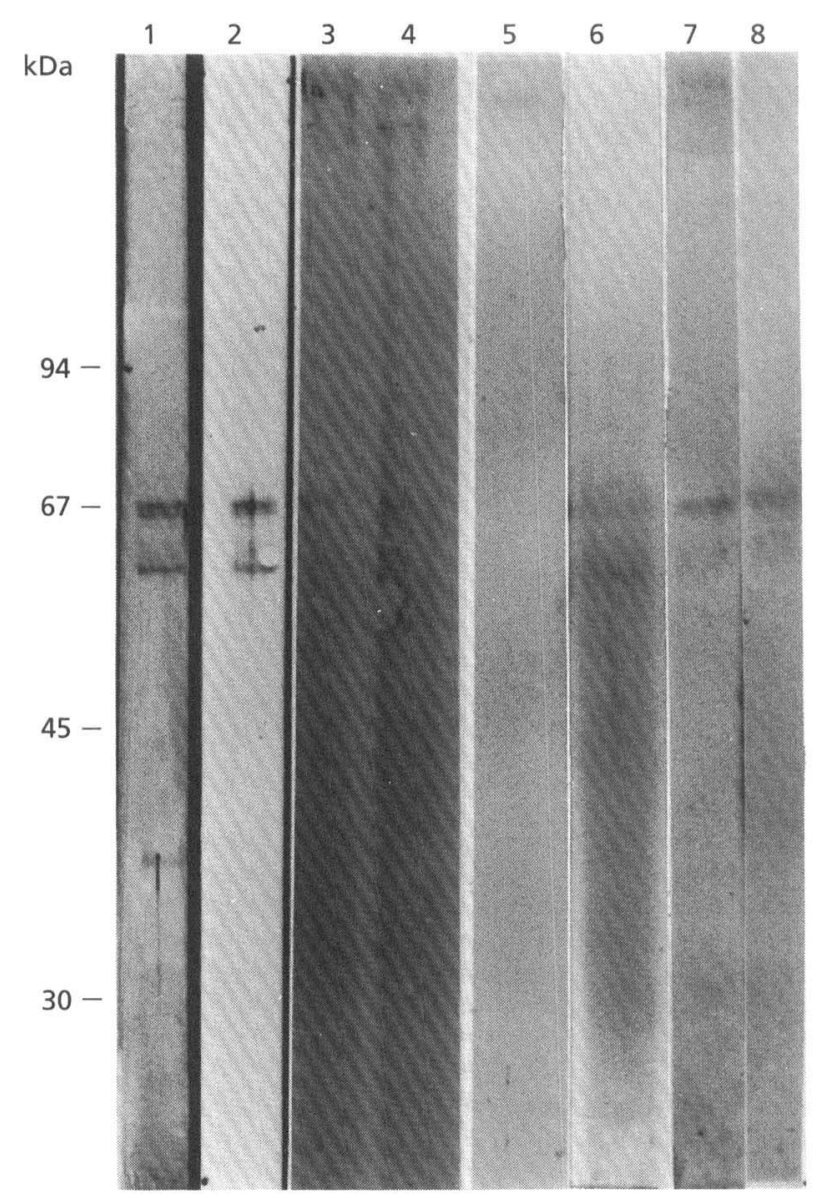

Fig. 2. Glycoprotein fraction electrophoresed and blotted onto Hybond C membrane. Lanes: 1, blot stained with India ink for total protein; 2, 3, 4 and 5, blots probed with homologous antiserum; 3 and 4 , after pretreatment with periodate for $2 \mathrm{~h}$ and $18 \mathrm{~h}$, respectively; 5 , pretreated with dilute $\mathrm{HCl} ; 6$, probed with LCA, biotin conjugated; 7, probed with serum from a patient with aspergilloma; 8 , probed with antiserum raised in rabbits against carbohydrate-rich antigen. Molecular mass markers are shown on the left.

When this blot was treated with homologous antiserum, raised in rabbits, a reaction was seen with the bands at 60 , 66 and $68 \mathrm{kDa}$. In a total of ten batch preparations, these antigenic bands were quite reproducible. A representative sample is shown (Fig. 2, lane 2). That the antigenic epitopes were, in large part, carbohydrate in nature was shown by their susceptibility to periodate oxidation, which abolished much of their antigenic activity (Fig. 2, lanes 3 and 4). Pretreatment with dilute acid completely destroyed the antigenicity of these molecules (Fig. 2, lane 5). The glycoprotein nature of these molecules was further supported by their ability to bind to a lectin (LCA) with sugar specificity for $\alpha$-D-glucose and/or $\alpha$-D-mannose residues (Fig. 2, lane 6). Some additional components, of lower molecular mass, were also bound by this lectin. WGA and ConA did not bind to these molecules (results not shown). However, an antiserum raised in rabbits to a ConA-binding fraction of $A$. fumigatus water-soluble material bound specifically to the band doublet of 


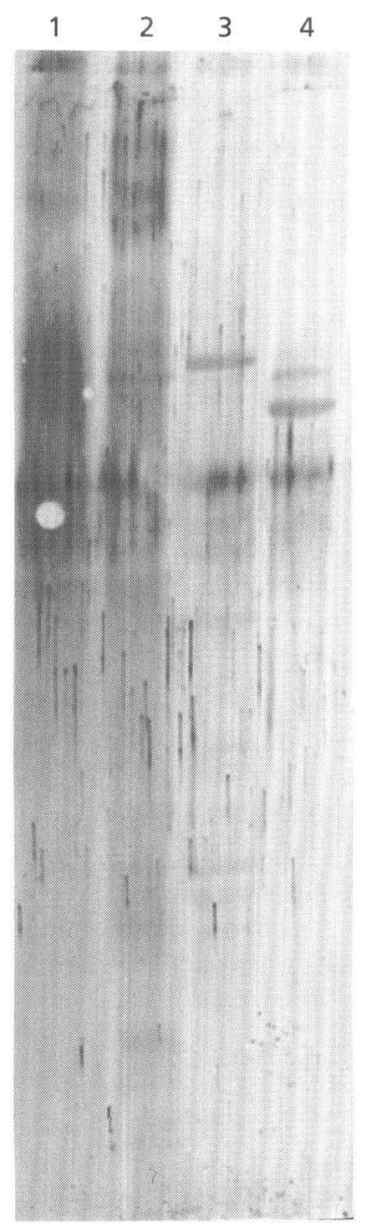

Fig. 3. Blots of different extracts of $A$. fumigatus probed with antiserum against the glycoprotein fraction. Lanes: 1, surface antigens; 2, water-soluble fraction; 3, protein-rich fraction; 4, carbohydrate-rich fraction.

apparent molecular mass $66-68 \mathrm{kDa}$ (Fig. 2, lane 8). Serum from patients with aspergilloma also had antibodies which recognized these antigens (Fig. 2, lane 7). Antibodies were detected in the limited sample size tested (total $=$ seven individual patients plus a pooled sample). Similar band patterns were obtained in each case.

That these antigenic epitopes are widely distributed in various fractions of $A$. fumigatus was shown by the ability of homologous antiserum to bind to surface-located as well as cytoplasmic antigens. These antibodies bound to antigenic sites of both carbohydrate-rich and protein-rich fractions of $A$. fumigatus (Fig. 3).

\section{Effect of enzymes on antigen/antibody binding}

Treatment of blots with either galactose oxidase or $\alpha$ mannosidase had no detectable effect on the ability of the antigenic epitopes to bind to specific antibody. In contrast, the hydrolytic enzyme of $T$. harzianium, with specificity for $\beta$-D-galactofuranosyl residues, when used in this system in large excess destroyed antigenic activity.

\section{DISCUSSION}

The hyphal wall of $A$. fumigatus can be separated into several fractions by sequential alkali and acid treatment. Analysis showed a cell wall consisting of a glucan/chitin complex with similarities to the previously defined wall of Aspergillus nidulans (Bull, 1970). An alkali-soluble extract was obtained which was precipitated by acidification. This fraction consisted mainly of glucan and displayed an $\mathrm{X}$-ray diffraction pattern similar to $(1 \rightarrow 3)$ - $\alpha$-glucan (Kreger, 1954; Bacon et al., 1968). This type of glucan has been reported to be present in several fungal species (Wessels \& Sietsma, 1981).

Following removal of this glucan from the alkali-extract the remaining material was precipitated with ethanol. It appeared to consist of a gluco-galacto-manno-protein. On SDS-PAGE this glycoprotein complex showed major components of apparent molecular mass between 60 and $68 \mathrm{kDa}$ which reacted with antibodies raised in rabbits against defined $A$. fumigatus extracts and with sera of patients with aspergilloma. The glycoprotein nature of these components was shown by their ability to bind to LCA with specificity for $\alpha$-D-glucose and/or $\alpha$-D-mannose residues. Failure to detect binding to $\operatorname{Con} A$ may be due to the lower sensitivity of peroxidase reagents in comparison with biotin-conjugated reagents.

Modification of some of the glyco- part of the glycoprotein by periodate treatment removed much of the antibody-binding capacity. Antigen sensitivity to a $\beta$ galactofuranosidase implicates galactose residues in this reaction. However, a large excess of this enzyme was required to destroy antigen/antibody binding (cf. Van Bruggen-Van der Lugt et al., 1992), and this enzyme is contaminated with small amounts of glucanase and exo- $\alpha$-D-mannanase (De Ruiter et al., 1994). These results and reactivity towards antisera raised to carbohydrate and protein components of $A$. fumigatus indicated that both of these types of structures are antigenic. Components with similar epitopes are probably excreted into the medium or loosely attached to the outer wall as water-soluble material (Hearn et al., 1990).

The alkali-insoluble fraction consists of a glucan/chitin complex which seems to be present in almost all fungal species and probably plays a dominant role in fungal morphogenesis (Sietsma \& Wessels, 1991). Following treatment with nitrous acid, most of the glucan that was initially alkali-insoluble became soluble in $\mathrm{KOH}$. Nitrous acid is thought to specifically disrupt glycosidic linkages involving glucosamine. We therefore conclude that in this organism the glucan is linked to chitin through a linkage in which glucosamine is involved. $N$-Acetylglucosamine seems also to be involved because a portion of it $(16.4 \%$ of the amount present in the alkali-insoluble fraction) becomes alkali-soluble after nitrous acid treatment and thus does not show properties characteristic of genuine chitin, which remains alkali-insoluble after nitrous acid treatment. In Schizopbyllum commune it was shown that beside these amino sugars, some amino acids, especially lysine, seemed also to be involved in the linking of glucan to chitin. However, the exact type of linkage was not 
elucidated (Sietsma \& Wessels, 1979). In Candida albicans a $(1 \rightarrow 6)$ linkage was found between glucose and $N$ acetylglucosamine (Surarit et al., 1988) which could be part of this linkage. Again the exact nature of this linkage is still speculative. It is possible that different fungal species may use different types of linkage.

In general it is found that the glucan in the alkali-insoluble part of the hyphal wall of fungi not only contains $(1 \rightarrow 3)$ $\beta$ linkages but also $(1 \rightarrow 6)-\beta$ linkages. The presence of the latter linkage type was not further investigated in this study; however the detection of hydroglucan X-ray diffraction lines in untreated wall preparations (Fig. 1) indicates that the glucan chains are arranged in such a way that they are able to form triple helices stabilized by $\mathrm{H}$ bridges (Jelsma \& Kreger, 1979). This suggests that if $(1 \rightarrow 6)$ linkages were present, they are unlikely to be abundant. To date the only report of walls containing a glucan consisting exclusively of $(1 \rightarrow 3)-\beta$ linkages is for those of Didymella bryoniae, a pathogen of cucumber plants (van Pelt-Heerschap \& Sietsma, 1990).

The results of this study also show that crystallization of the $(1 \rightarrow 3)$ - $\beta$-glucan and chitin is hampered by the covalent linkages to each other. When these linkages are broken by nitrous acid, both substances become more crystalline, as shown by a more pronounced X-ray diffraction pattern.

The amino sugars [( $\mathrm{N}$-acetyl $)$ glucosamine] in the wall play different roles: $7 \cdot 6 \%$ are alkali-soluble and are probably part of a glycoprotein; a small proportion, $4.9 \%$, can be removed by nitrous acid and is therefore present in the form of glucosamine; after nitrous acid treatment $16.4 \%$ become alkali-soluble indicating that they are separated from the poly- $N$-acetylglucosamine main chains by a linkage containing glucosamine; the remaining $72.3 \%$ display properties corresponding to $\alpha$-chitin.

The apparent involvement of glucosamine in the linkage of glucan to chitin in this organism is remarkable. In $A$. nidulans and Neurospora crassa it was shown that deacetylated amino sugars do not play a significant role ( $\mathrm{Mol}$ et al., 1988). In the yeast species Saccharomyces cerevisiae and Scbizosaccharomyces pombe (Mol \& Wessels, 1987; Sietsma \& Wessels, 1991), and also in some basidiomycetes, e.g. Scbizopbyllum commune and Agaricus bisporus, the involvement of glucosamine was inferred (Wessels et al., 1989). Larger amounts of deacetylated glucosamine (chitosan) generally occur in the hyphal walls of zygomycetes (Kreger, 1954; Datema et al., 1977; Davis \& BartnickiGarcia, 1984). Chitosan is also present in the walls of the ascospores of Sacch. cerevisiae in considerable amounts (Briza et al., 1988). It could be that this partly deacetylated chitin is a more general phenomenon, important in the process of polysaccharide inter-linking.

\section{REFERENCES}

Alon, R., Bayer, E. A. \& Wilchek, M. (1991). A coupled enzyme assay for measurement of sialidase activity. J Biochem Biophys Method's 22, 23-33.

Azuma, I., Kimura, H. \& Yamamura, Y. (1968). Purification and characterization of an immunologically active glycoprotein from Aspergillus fumigatus. J Bacteriol 96, 272-273.

Azuma, I., Kimura, H., Hirao, F., Tsubura, E. \& Yamamura, Y. (1969). Biochemical and immunological studies on aspergillus. II. Immunological properties of protein and polysaccharide fractions from Aspergillus fumigatus. Mycopathol Mycol Appl 37, 289-303.

Bacon, J. S. D., Jones, D., Farmer, V. C. \& Webley, D. M. (1968). The occurrence of $\alpha-(1-3)$-glucan in Cryptococcus, Schizosaccharomyces and Polyporus species and its hydrolysis by a streptomycete culture filtrate lysing cell walls of Cryptococcus. Biocbim Biopbys Acta 158, 313-315.

Briza, P., Ellinger, A., Winkler, G. \& Breitenbach, M. (1988). Chemical composition of the yeast ascospore wall. J Biol Chem 263, 11569-11574.

Bull, A. T. (1970). Chemical composition of wild-type and mutant Aspergillus nidulans cell walls. The nature of polysaccharide and melanin constituents. J Gen Microbiol 63, 75-94.

Datema, R., van den Ende, H. \& Wessels, J. G. H. (1977). The hyphal wall of Mucor mucedo. Eur J Biochem 80, 621-626.

Davis, L. L. \& Bartnicki-Garcia, S. (1984). Chitosan synthesis by the tandem action of chitin synthetase and chitin deacetylase from Mucor rouxii. Biocbem J 23, 1065-1068.

De Ruiter, G. A., Van Bruggen-Van der lugt, A. W., Mischnick, P., Smid, P., Van Boom, J. H., Notermans, S. H. W. \& Rombouts, F. M. (1994). 2-O-Methyl-D-mannose residues are immunodominant in extracellular polysaccharides of Mucor racemosus and related molds. $J$ Biol Chem 269, (in press).

Drouhet, E., Camay, L. \& Segretain, G. (1972). Valeur de l'immunoprecipitation et de l'immunofluorescence indirecte dans les aspergilloses broncho-pulmonaires. Ann Inst Pasteur 123, 379-395.

Fairbairn, N. J. (1953). A modified anthrone reagent. Chem Ind 72 , 86.

Hancock, K. \& Tsang, V. C. W. (1983). India ink staining of proteins on nitrocellulose paper. Anal Biochem 133, 157-162.

Hearn, V. M. (1991). Glycoproteins of Aspergillus fumigatus cell wall. In Fungal Cell Wall and Immune Response, pp. 219-228. Edited by J. P. Latge \& D. Boucias. Berlin: Springer-Verlag.

Hearn, V. M. \& Mackenzie, D. W. R. (1979). Mycelial antigen from two strains of Aspergillus fumigatus: an analysis by two-dimensional immuno-electrophoresis. Mykosen 23, 509-562.

Hearn, V. M., Griffiths, B. L. \& Gorin, P. A. J. (1989). Structural analysis of water-soluble fractions obtained from Aspergillus fumigatus mycelium. Glycoconjugate J 6, 85-100.

Hearn, V. M., Wilson, E. V., Latge, J. P. \& Mackenzie, D. W. R. (1990). Immunochemical studies of Aspergillus fumigatus mycelial antigens by polyacrylamide gel electrophoresis and Western blotting techniques. J Gen Microbiol 136, 1525-1535.

Hearn, V. M., Latge, J. P. \& Prevost, M. C. (1991). Immunolocalization of Aspergillus fumigatus mycelial antigens. J Med Vet Mycol 29, 73-81.

Jelsma, J. \& Kreger, D. R. (1979). Polymorphism in crystalline (1-3)- $\beta$-D-glucan from fungal cell walls. Carbobydr Res 71, 51-64.

Johnson, A. R. (1971). An improved method of hexosamine determination. Anal Biochem 44, 628-635.

Kreger, D. R. (1954). Observations on cell walls of yeasts and some other fungi by $\mathrm{X}$-ray diffraction and solubility tests. Biochim Biophys Acta 13, 1-9.

Laemmli, U. K. (1970). Cleavage of structural proteins during the assembly of the head of bacteriophage T4. Nature 227, 680-685.

Mol, P. C. \& Wessels, J. G. H. (1987). Linkages between gluco- 
saminoglycan and glucan determine alkali-insolubility of the glucan in walls of Saccharomyces cerevisiae. FEMS Microbiol Lett 41, 95-99.

Mol, P. C., Vermeulen, C. A. \& Wessels, J. G. H. (1988). Glucanglucosaminoglycan linkages in fungal walls. Acta Bot Neerl 37, 17-21.

Nelson, N. (1944). A photometric adaptation of the Somogyi method for the determination of glucose. J Biol Chem 153, 375-380.

van Pelt-Heerschap, H. \& Sietsma, J. H. (1990). Analysis of the hyphal wall of Didymella bryoniae: composition and sensitivity to hydrolytic enzymes. Mycol Res 94, 979-984.

Shively, J. E. \& Conrad, H. E. (1970). Stoichiometry of the nitrous acid deaminative cleavage of model aminoglucan glucosides and glycosaminoglycuronans. Biochemistry 9, 33-43.

Sietsma, J. H. \& Wessels, J. G. H. (1979). Evidence for covalent linkages between chitin and $\beta$-glucan in a fungal wall. $J$ Gen Microbiol 114, 99-108.

Sietsma, J. H. \& Wessels, J. G. H. (1991). Cell wall assembly in fungal morphogenesis. In Fungal Cell Wall and Immune Response, pp. 81-95. Edited by J. P. Latge \& D. Boucias. Berlin: SpringerVerlag.

Stahl, E. (1969). Thin-layer Chromatograpby. Heidelberg: SpringerVerlag.

Surarit, R., Gopal, P. K. \& Shepherd, M. G. (1988). Evidence for a glycosidic linkage between chitin and glucan in the cell wall of Candida albicans. J Gen Microbiol 129, 1607-1616.

Towbin, H., Staehelin, T. \& Gordin, J. (1979). Electrophoretic transfer of proteins from polyacrylamide gels to nitrocellulose sheets: procedure and some applications. Proc Natl Acad Sci US A 76, 4350-4354.

Van Bruggen-Van der Lugt, A. W., Kamphuis, H. J., de Ruiter, G. A., Mischnick, P., Van Boom, J. H. \& Rombouts, F. M. (1992). New structural features of the antigenic extracellular polysaccharides of Penicillium and Aspergillus species revealed with an exo- $\beta$-Dgalactofuranosidase. J Bacteriol 174, 6096-6102.

Wessels, J. G. H. \& Sietsma, J. H. (1981). Fungal cell walls: a survey. In Encyclopedia of Plant Physiology, New Series, vol. 13B, pp. 352-394. Edited by W. Tanner \& F. A. Loewus. Heidelberg: Springer-Verlag.

Wessels, !. G. H., Mol, P. C., Sietsma, J. H. \& Vermeulen, C. A. (1989). Wall structure, wall growth and fungal cell morphogenesis. In Biochemistry of Cell Walls and Membranes in Fungi, pp. 81-95. Edited by P. J. Kuhn, A. P. J. Trinci, M. J. Jung, M. W. Goosey \& L. G. Copping. Berlin: Springer-Verlag.

Wilson, E. V. \& Hearn, V. M. (1983). Use of Aspergillus fumigatus mycelial antigens in enzyme-linked immunosorbent assay and counter-immunoelectrophoresis. J Med Microbiol 16, 97-105.

Zamze, S. E., Ashford, D. A., Wrenn Wooten, E., Rademacher, T. W. \& Dwek, R. A. (1991). Structural characterization of the asparagine-linked oligosaccharides from Trypanosoma brucei type II and type III variant surface glycoproteins. I Biol Chem 266, 20244-20261.

Received 21 June 1993; revised 30 September 1993; accepted 26 October 1993. 